\title{
Plants that can be Poisonous for Cows. A Review
}

\author{
Cristina EL MAHDY1*, Silvana POPESCU², Cristin BORDA* \\ ${ }^{1}$ Department of Fundamental Sciences, University of Agricultural Sciences and Veterinary Medicine, \\ Cluj - Napoca, Romania \\ ${ }^{2}$ Department II Animal Production and Food Safety, University of Agricultural Sciences and Veterinary \\ Medicine, Cluj-Napoca, Romania
}

${ }^{*}$ Corresponding author, e-mail: popescusilvana@yahoo.com

Bulletin UASVM Animal Science and Biotechnologies 74(2)/ 2017

Print ISSN 1843-5262; Electronic ISSN 1843-536X

DOI:10.15835/buasvmcn-asb: 0019

\begin{abstract}
Romania is blessed with a rich spontaneous flora, but some of the plants are toxic by their consumption in cattle, affecting the health, productions and endangering consumer safety. Sometimes even the consumption of small amounts causes poisoning with a broad extension: from mild, moderate to severe and with chronic or acute manifestations. Plant action is not similar. Taxus Buccata, Eupatorium spp. (E. rugosum, E. urticaefolium, E. ogeratoides) are cardiotoxic plants, but, Eupatorium spp. also acts through depression of the central nervous system; Datura stramonium (Jimson weed), Solanum spp. (nightshades), Atropa belladonna (belladonna), are plants with cholinergic blocking; haemolytic anemia is caused by Pteridium aquilinum (Bracken fern) and Equisetum (horsetail). The poisoning with cyanogenic principles occurs at Sorghum spp (Johnson grass, sudan grass); Elderberry consumption, Senecio spp. and Hypericum (St John's wort) induces liver toxicity. Plants containing alkaloids outside their toxicity also have teratogenic action: Lupinus spp., Nicotiana spp, Conium maculatum, Veratrum album. However, some of these plants can be used in certain cows' treatments.
\end{abstract}

Keywords: ethnoveterinary, plants, poisonous, symptoms

\section{INTRODUCTION}

Grazing, although it has many advantages, can expose the animals to a series of illnesses and accidents (Drăghici, 1991), especially when the green mass is reduced quantitatively and qualitatively, favoring the consumption of plants that cause intoxication (Voia et al., 2009).

In the choice of plant species or parts of them, responses to chemical stimuli received by the animal through, smell, taste or touch and the existing components: carbohydrates, organic acids, tannins or alkaloids present (Arnold et $a l ., 1981$ ) is the secret weapon in selecting forage. Ruminants use all the senses in selecting plants, and the smell seems to complement the taste that remains the primary factor. Unpalatable or nonswallowable feeds are discarded before being swallowed (Lyons et al., 2000).
It is true that there are a number of factors that contribute to poisoning: the season and the weather conditions the animals are subjected to: transport, handling, when they are not regularly fed and fed and the quality of the pasture is poor (Panter et al., 2011).

It is necessary for the animals to receive appropriate and good quality feed which allows the animals to avoid the consumption of toxic plants, otherwise the cows, fed up with the same diet are tempted to consume toxic plants which grow along the pasture and the fence, although have low palatability (Baldwin et al., 2011).

As a rule, poisoning occurs through the consumption of the whole plant or parts of it which is toxic, depending on the amount consumed, the period of the year and the stage of maturity of the plant, the quantity of water in the feed, the state of 
health of the animals, their age and weight (www. co.lancaster.pa.us, 2010), physiological state (Cortinovis et al., 2015), the nature of the toxic principles, the environmental conditions in which the plants live (Bosworth, 2006).

Although poisoning can occur throughout the year, because some plants by drying and present in the hay do not lose their toxicity (Puschner et $a l ., 2003)$, grazing the early pasture in the spring when the toxic plants make their first appearance, represent danger of poisoning (Panter et al., 2011). In general, plant toxins are perceived by the brain in an interval of 4-12 hours after ingestion of the feed (Arnold G.W. et al., 1981), but the identification of the causes is hard to analyze, which is why the detection of toxic plants, the understanding of the symptoms, the recognition of problem areas represent the strategy for minimizing the hazards (Hart et al., 2001).

The toxic principles in plants are multiples: alkaloids, glycosides, cyanogenic glycosides, toxalbumin, but, most cases of poisoning in cows are due to plants containing alkaloids: Colchicum autumnale (meadow saffron),Conium maculatum (poison hemlock), Datura stramonium (jimson weed), Equisetum palustre (marsh horsetail), Senecio spp. (ragwort), Taxus baccata (European yew) after Cortinovis et al. (2015). A number of plants whose parts are toxic are generally avoided by animals, but not when they are found in the hay. The most common toxic plants present in hay: Atropa belladona, Conium maculatum, Datura stramonium, Euphorbia spp., Veratrum album, Colchicum autumnale (http://agriculturaonline. blogspot.ro, 2011). Some of the clinical signs of poisoning in cows are similar, the manifestations being nervous and reproductive: Lupinus spp., Nicotiana spp, Veratrum album, Conium maculatum (Forero et al., 2011). Calf birth defects manifested by malformations of the legs, spine and throat as well as palate cleft are caused by the consumption of toxic plants during the gestation period of the cows in the range of 55-75 days (Conium maculatum, Lupinus); 45-75 days Nicotiana spp. (Panter, 1999).

Plants such as: Equisetum, Pteridium aquilinum, has the same antivitamin B1: thiaminase factor, with similar but also distinct symptoms depending on the other principles (Bosworth, 2006).

Digitalis sp, Adonis vernalis, Convallaria majalis, causes cardiac disorders due to its content in cardiac glycosides (Pushner et al., 2003, Chaney, 2015, Zanoschi et al., 1981).

Consumer safety is endangered if milk comes from poisoned cows with: Lupinus spp, Equisetum spp., Aconitum spp., Atropa belladona, Euphorbia spp., Pteridium aquilinum (Rasnoveanu, 2013).

\section{POISONING WITH PLANTS CONTAINING VARIOUS TOXIC PRINCIPLES}

\section{PoISONING WITH PLANTS CONTAINING ALKALOIDS}

Lupine can tolerate less fertile soils, due to the massive root system, which is why it has wide spread area (Markéta et.al., 2005).

The alkaloids present in lupine (Lupinus luteus, L.albus, L.angustifolius, L. perennis) lupinine and sparteine are found in large quantities. Spartulatine, lupanine, hidroxilupanine are other alkaloids present in lupine plants, but, especially in variety L. angustifolius (Zanoschi et al., 1981). The plant is evaluated as having a moderate / high degree of toxicity (Glen, 2008).

Disorders of: nervous system, liver degeneration, heart, kidneys and muscles occur mainly by eating before the flowering of the plant and then, by eating lupine seeds (El Mahdy, 2015).

Intoxication, caused by Phomopsis leptostromiformis, fungus, called lupinosis, attacks Lupinus luteus seeds and grows saprofit along with the species L. albus and L. Angustifolius; the symptoms manifestingby high hepatotoxicity (Bhat et al., 2010).

Signs of poisoning: changes in behavior, spasms, vomiting, abdominal pain, tremors, excitement, head pressure, difficulty breathing, loss of coordination, salivation, convulsions (Baldwin et al., 2011; Chaney, 2015).

The reproductive sphere is also affected by cows' consumption of certain lupine varieties, because, not all species are equally toxic, and, bitter varieties that contain quite large amounts of alkaloids should not be administered as feed for animals (Baldwin et al., 2011). The negative repercussions on future newborn calves are manifested through obtaining calves with multiple congenital deformations (D'Mello, 2002). Due to another present alkaloid, by quinolizidine type (Dąbrowski et al., 2005) - anagyrin, with teratogenic effects (Markéta et.al., 2005), can 
affect pregnant cows fed on lupine in the first 40-70 days of gestation can calving, calves, with deformations known as "crooked calf syndrome", similar to those caused by consumption of Conium (Glen, 2008). Contamination of milk is possible when large amounts of lupine are consumed (Meriçli, http://docs.neu.edu.tr,).

Jimsonweed, thornapple (Datura stramonium), is an annual plant which we find it in uncultivated or cultivated places, in the field, especially among soy and corn crops. The plant prefers rich soils (www.co.lancaster.pa.us, 2010). Due to the fact that, fresh plant, has strong smell and unpleasant taste is not consumed by animals, just in case they are hungry or pastures has low value and infested with Jimsonweed (http://www. welchproperty.com/,). In this case, poisoning occurs within few minutes or hours (Bosworth, 2006). Regardles that, the plant is green or dry, the toxicity remains the same, but the seeds and root are the most toxic parts (Glen, 2008; Wink, 2009). In green state, more than $0.7 \%$ of green leaf weight contains toxic alkaloids, and nectar also contains toxic principles (Bosworth, 2006). The seeds have low palatability, therefore it will not be consumed only if they are found in hay, silage or grain (Kerr, http://extension.wsu.edu,).

Poisoning occurs mainly when the seeds of this plant reach in the freshly cut hay or corn intended for ensiling (Binev et al., 2010), in which case, it is noted self-limiting consumption by ruminant atony and anorexia to prevent further intoxication until the level of alkaloids of the blood is reduced and allows the normal intestinal function of ruminants (Nelson et al.,1982). Alkaloids present in the plant: atropine, scopolamine, hyoscyamine (Fuchs et al., 2011), have strong anticholinergic properties (Soler-Rodríguez et al., 2006). But the plant also contains: daturine, and may contain a large amount of nitrates (Mezzasalma et al., 2016).

Incipient symptoms are manifested by rapid pulse and increased heart rhythm, pupil dilatation, vision impairment, dry mouth and other mucosae, animals looking for a source of water to quench thirst (Hansen et al.,2002; Everest et al., 2005). Later, the symptoms are transposed by: decreased body temperature, nausea, loss of muscle coordination, aggressive behavior, violent, tremors, breathing disorder manifested by slow breathing, rapid and weak pulse, fever, delirium (www.envbop.govt.nz, 2003), the cattle appear to be hallucinating, have convulsions, become comatose, and possibly die (Fishel, 2001). Poisoning occurs at the consumption of 0.250$0.453 \mathrm{Kg}$ of green plant (Zanoschi et al., 1981), and, after Boyd et al. (https://www.uaex.edu/), ingestion of an amount of seed between 0.06 to $0.09 \%$ of animal weight can be fatal in cows.

Both, Datura stramonium and Colchicum autumnale cause dysphagia, toxic dystrophy of the liver and sometimes cardiac lesions, cardiopulmonary collapse (Mezzasalma et al., 2016). Milk from poisoned cows is contaminated (Jonker, 2015).

Nicotiana tabacum (lowland region), $N$. rustica (higher areas in the northern region of the country) (Zanoschi etal., 1981), contains especially in leaves and seeds $2-3 \%$ of the most toxic principle, nicotine (Nellis, 1997), which affects the nervous system along with another alkaloid, pyridine (https://www.coursehero.com/, 2015). But the number of alkaloids from the leaves is much higher: methylanabasine, acetylnornicotine, acetylanatabine, acetylanabasine (Garland et al., 1998).

Although poisoning with Nicotiana spp. are infrequent, the effects of nicotine consumption consist of: hair scarring, trembling, restlessness, salivation, nausea, bloating, constipation followed by feverish, diarrhea, accelerated breathing and gasping, heartbeat rare at first that become accelerated and irregular, cardiac arrhythmia, extremity cooling, dizziness, loss of sensitivity, strong ptialism, catarrhal gastro- - enteritis, polyuria, tonic convulsions followed by muscle paralysis, and death (Zanoschi et al., 1981; http:// poisonousplants.ansci.cornell.edu/, 2015; Forero et al., 2011).

Hassine et al., (2013) describes the sequential stages of intoxication in cows, the first phase consisting of generalized tremor, hypersalivation, conjunctivitis, rapid loss of sensitivity, sphincter relaxed and palidity of mucous membranes, followed by the second stage, the imbibition, manifested by hypotension, bradycardia and dyspnea, eventually leading to coma and respiratory insufficiency (Schep et al., 2009). Coma it's installing depending on the form of intoxication: 1-2 hours after ingestion (acute poisoning) and 1-3 days (subacute poisoning) 
(Zanoschi et al., 1981).

According to the same author, animals should not have access to tobacco plants, and $0.5-2 \mathrm{Kg}$ leaves induce state of toxicity in cattle.

The teratogenic effect of Nicotiana it is considered to be identical to that of Lupinus and Colchicum, by induction of malformations and clef palate on calves, result of reduced fetal movement (Welch et al., 2012), during critical stages of gestation (Dąbrowski et al., 2005).

Colchicum autumnale (Meadow saffron, Autumn crocus), plant whose presence indicates grassland or hayfields with high ecological quality are found in hayfields, wet soils rich in substances important for plant growth (www.rndr.ro/ documente/, 2015).

Colchicine, alkaloid, is present in the whole plant being, capillary toxic and paralyzing effect of the nervous system. In the category of animals susceptible to poisoning, ranging from moderate to severe toxicity (Glen, 2008) includes cattle which grazes surfaces in whose floral composition the plant is found, or in the field (Seceleanu, 2015), especially in spring when, the leaves are in young stage and, autumn through the ingested flowers (Anadón et al.,2012).

The leaves are toxic at a consumption of $0.1 \%$ of the animal's weight (http://poisonousplants. ansci.cornell.edu/, 2015). Clinical manifestations and signs that typically occur 48 hours after ingestion are: pain in the mouth and throat, vomiting, salivation, dysphagia, lethargy, low blood pressure, abdominal pain, colic, diarrhea and faeces foul-smelling, tenesmus (Cortinovis et al., 2015). In more serious cases, following the consumption of large quantities of the plant: shock, convulsions and coma precede the end, that is, the death of animals (Chaney, 2015). The alkaloid is heat-resistant, is not destroyed at high temperatures, the silage and hay being toxic as well, when they have many leaves of Colchicum autumnale in their composition because colchicine is able to withstand storage and drying (Voia et al., 2009). The calves fed with milk coming from poisoned cows leads to their intoxication (http:// poisonousplants.ansci.cornell.edu/, 2015). Colchiceine, another alkaloid, is manifested by diarrhea, black-green bloody feces, hepato-renal disorders, polyuria and haematuria, nervous disorders, bulbar respiratory paralysis, cattle mortality may be between $25-50 \%$. (Zanoschi et al., 1981).

Equisetum arvense, E.palustre, E.fluviatile (field horsetail), is not one of the plants preferred by cows, due to the large amount of silicon which reduces its palatability. Of the Equisetum species, E. palustre which grows around the marshes is the most poisonous, but, the spreading area of the plant is much wider (Popescu et al., 1981). We meet on drained soils, sandy soil or gravel with proper drainage (Zanoschi et al., 1981). The toxicity of the plant is given by its aerial parts (Wink, 2009). Regardless of the form under which it is consumed: a green or dry plant has a toxic character through principles existing in the plant: alkaloid- equisentin; enzyme thiaminase (Cramer, et al., 2015) with antivitamin $\mathrm{B}_{1}$ action, palustrine, palustridine and other alkaloids in a ratio greater than $0.3 \%$, as well as saponins (Wink, 2009).

Symptoms of poisoning assessed as having a moderate rate of intoxication in cows is manifested by: lack of appetite, emaciation, decrease in milk yield, digestive problems, diarrhea (Glen N., 2008). According to the same author, the poisoning caused by the prolonged administration of horsetail, causes respiratory and heart problems, cardiac arrhythmias and, in some cases convulsions. And because, young animals are more susceptible to poisoning than adults, Aboling et al., (2014) reports cases of haemorrhagic enteritis in pregnant heifers. Calves that consume contaminated milk will present convulsions, the head arched straight back and prefers the lying down position (Forero et al., 2010). The hay which contain this plant is toxic (Forero et al., 2010). Because both, horsetail and bracken fern, present the same antivitaminic factor $\mathrm{B}_{1}$ - thiaminase, the symptoms are similar. Difference consists in the fact that horsetail does not exhibitbone marrow toxin found in brackenfern and that affects the ruminants (Bosworth, 2006). At autopsy, it is not noticeable changes in organs but only diffuse lesions in the cerebral cortex, involving different nuclei of the brain, in similar to those in encephalomalacia or cerebro-cortical necrosis (http://poisonousplants.ansci.cornell. edu/, 2015).

Aconitum paniculatum, $A$. napellus $A$. moldavicum kind of very poisonous herbaceous plants commonly known as aconite, monkshood, 
wolf's bane, leopard's bane, mousebane, women's bane, devil's helmet, queen of poisons (https:// en.wikipedia.org,) grows in wetlands, rocky places and mountain meadows (http://www.biaplant. ro, 2015). All parts of the plant are toxic, but the concentration of toxic principles at wild species is higher in the roots and root tubers (Chan T.Y., 2009), and at $A$. napellus the roots, the seeds and the pre-flower leaves are especially toxic (https:// csuvth.colostate.edu,2017). Poisoning in cows is manifested through: disorders of the nervous system, paralysis of bulb nervous centers, cardiac and respiratory (Nualláin, 2014) due to the high content of aconitine, the strongest poison of the nervous system that activates the sodium channels being a powerful toxin of the nerves and muscles that cause it numbness and paralysis (Wink, 2009); aconin and benzoliaconine (https:// www.scribd.com/), mesaconitine, lycoctonine; are other toxic principles that are also part of the terpenoid alkaloids category (Zanoschi et al., 1981). Aconitin is easily absorbed in the digestive tract and is slowly eliminated by the kidney. The manifestations of poisoning are accompanied by vomiting, colic, constipation, slowing of heartbeats and breathing, pupil dilation, muscle tremors and weakness (Gintaras, 2012), polyuria, hypothermia and death, in severe cases. After Constable et al., (2017), the diarrhea that can accompany poisoning is attributed to the existence of other additional toxic principles.

Apart from neurotoxic principles, cardiotoxic agents act by increasing the sodium ions permeability and membrane excitability (Acamovic et al., 2004). Toxins can also be absorbed through the skin (http://www.realgardeners.co.uk/,).

Pastures in whose vegetation is more than $10 \%$ monkshood need to be cleaned because the plant toxicity is high, both, green and dry state (http://www.triplecrownhorsefeeds.com/,). It is not allowed to consume milk from poisoned animals with monkshood (Rasnoveanu, 2013).

Taxus buccata (European yew) known as " the tree of death ", is a arboretums much more widespread in the past, but, should not be overlooked because it is extremely toxic (Zanoschi et al.,1981). In Romania it appears disseminated from the hills to the mountainous area, in the beeches or mixtures of beech with resin on rugged relief, rocky areas, screes, in the form of isolated specimens, or bouquets (http://www.plantpedia. ro, 2010).All parts of the tree, less the fleshy part of the red fruit, dead or alive, are toxic, but especially leaves, the toxicity rate being high throughout the year (Wright et al., 2007).The plant contains a number of toxic principles: alkaloids (taxin A, $\mathrm{B}$ and $\mathrm{C}$ ) that suppress the activity of the heart; glycosides (taxicatine), hydrocyanic acid esters, ephedrine, taxol, and other principles (http:// poisonousplants.ansci.cornell.edu, 2015). Taxin $\mathrm{A}$ and $\mathrm{B}$ are cardio-depressant, death occurs suddenly, and, oil found in the sap has irritating action on the gut, being incriminated in colic and diarrhea.

Consumption of moderate amounts causes digestive discomfort from mild to severe when the animal can succumb. Schivera, (2011) is of the opinion that, small quantities can kill the animal. Consumption of $0.5 \%$ of the weight of ruminants is sufficient to show signs of poisoning (Wilson et al., 2001). On the other hand, Cortinovis et al., (2015) suggests that ingestion of $0.5 \%$ of body weight for ruminants is fatal.

Manifestations of poisoning, which occur in cows at 24-48 hours after ingestion, consist of: ataxia, diarrhea, hypotension, colic, hypothermia, seizures, weakness, respiratory failure, bradycardia, coma and death, cardiac and/or respiratory collapse (Bosworth, 2006).

Senecio vulgaris and S. jacobea (Ragwort and Groundsel "stinking willie), grows throughout the country, in uncultivated places, besides walls, roads, or fields (https://ro.wikipedia.org/). Contains alkaloids of which: senecionine, senecine, senocifidine, are the most toxic (Zanoschi et al, 1981).

But the plant is much more rich in alkaloids: jacidine, jacobine, jacoline, jaconine, jacozine and retrorsine (Anadón et al., 2012), existing over 50 principles with cumulative hepatotoxic properties (El Mahdy., 2015). Poisoning with Senecio extends from moderate to severe, all parts of the plant being toxic (Chaney, 2015). Manifestations of poisoning may occur within 2-8 months after ingestion, not just immediately, period in which animals lose their physical condition and jaundice is installed, caused by liver failure. In some cases, the cows present photosensitivity (Puschner et al., 2003).

All farm species are susceptible to 
consumption of Senecio, but especially cows and horses, where the plant consumption produces fatal liver damage. Extending the effect, however, is much wider due to the mutagenic and carcinogenic action, and inhibition of peripheral nerves (Wink, 2009). Nervous system disorders are due to the high amounts of ammonia present in the blood (Cortinovis et al., 2015) which has as manifestations: staggering, circling and head pressing ((http://www.thecattlesite.com).

In the first stage of poisoning cows manifested as symptoms: lethargy, loss of appetite, reduction in the body condition score, crusting around the eyes and nose, red eyes and tears, gastroenteritis, diarrhea, constipation, weakness manifested by wobbling and dragging rear feet (https://www. ars.usda.gov, 2016). Walsh et al., (2007) has also noticed other changes to bulls poisoned with Senecio: depressive behavior, ears bent, gait, the absence of ruminal contractions, ascites. Sometimes the simptoms are accompanied by, diarrhoea, with straining, as well as jaundice - yellowing particularly of the whites of the eye. Cows may develop a pig-like odor that has a somewhat sweetish quality (http://www. thecattlesite.com/). The silage contaminated with less than 5\% Senecio, administered in ration in cows is considered unsafe (Forero et al., 2010). Not all species in this category are toxic but, $S$. jacobaea yes, which is why it should be removed from the floral composition, because, all parts of the plant are toxic and remain toxic and after they are preserved in the form of hay (www.defra.gov. uk/, 2009).

Conium maculatum- poison hemlock has as a spreading area: dry ditches, depreciated land surfaces (www.calivitavelcu.ro, 2009). The alkaloids: coniine and $\gamma$-coniceine are present throughout the plant, including: flowers, fruits, seeds. However, coniine is more concentrated in the leaves of the plant at the beginning of the vegetative stage, while the fruits incorporate the highest amount of coniine, in the autumn season (Cortinovis et al.,2015).

Although, the effects of alkaloids on the nervous system are not fully elucidated it is believed that they act like nicotine, that is, initially stimulate and then block the autonomic ganglia (Gintaras, 2012). By the alkaloid content, Conium affects the cows (Binev et al., 2007), the poisoning being manifested by acute neurotoxic, cardiovascular effects and fetotoxic effects including teratogenesis (Mezzasalma et al., 2016). Cows that have ingested Conium during 55-75 days of pregnancy (Panter et al., 1992) will give birth of calves with malformations of the neck, spine: arthrogryposis, scoliosis, torticollis, kyposis, and lordosis (Green et al., 2012); limbs: over-or under-extension or curvature of joints, rigidity of joints and immobility, clef palate (Panter et al., 1992). The obvious symptoms of intoxication are translated by: foam on the mouth, restlessness, pain, dilated pupils, jaw clamping, teething, vomiting, weak pulse, diarrhea, bloating, seizures, respiratory failure (Binev et al., 2007), gastrointestinal irritation, nervous irritation, neuromuscular blockade (Gintaras, 2012), cold extremities, and sometimes coma precede death of animals (Everest et al., 2005). Sometimes, plant consumption can cause dermatitis, and cow poisoning occurs at ingestion of over $2 \mathrm{~kg} / 400 \mathrm{~kg}$ of live weight (www.envbop.govt.nz, 2003). Who has any doubt on the plant is quite easy to identify. By crushing the plant, it leaves a bad smell similar to the smell of the mice (https://novascotia.ca,).

Although the name of the plant comes from the italian word "belladonna", which means beautiful woman, Atropa belladonna, is also known under other names as: belladonna, deadly nightshade, devil's berries, naughty man's cherries, death cherries, beautiful death, and devil's herb, being one of the most toxic plants, common in all the wooded regions of the Carpathians, frequented on the floor of the beech forests (Zanoschi et al., 1981).

Plant toxicity varies depending on the vegetation stage, but, the peak of toxicity is recorded during the fruiting stage (http://www. provet.co.uk). Contains alkaloids: atropine, scopolamine, hyosciamine, last two causing delusions and hallucinations, plus other principles such as: beladonine and nicotine (El Mahdy, 2015).

Poisoning is rare but possible, by ingestion of berries or contamination of feed (Largo, 2014). Symptoms of cow intoxication occur rapidly causing paralysis and death within 5-6 hours (http://www.belladonnakillz.com), and as manifestations: animals refuse the feed, maximal pupil dilation and iris reduction, dry mouth and thirst, bloating, restlessness, accelerated and 
weak pulse, heavy breathing, absent intestinal peristalsis, constipation, and the eye can not accommodate and the animals can prevent, acute tympanism (Zanoschi et al., 1981). Milk obtained from poisoned cows is contaminated, alkaloids reaching in its composition (http://www.provet. co.uk/).

A plant which grow on pastures, meadows, grassland, especially at high altitudes of Romania, Veratrum album (Hellebore), comes from latin 'vere', 'true', 'real', 'truly' plus 'ater', 'black' because of the roots of very intense black color (http:// www.thepoisongarden.co.uk,).

Veratrum acts as a modifier of muscle tonus and toxic bulbar, but, can cause dermatitis too, due to the principles that make it a violent vesicant (https://www.coursehero.com, 2015). The plant is toxic by its high alkaloid content, jervanine and veratranine type (veratridine, veratramine, veratrosine, jervine, pseudojervine, and isorubrijervine) and alkaloids with the cevanine skeleton (cevadine, cevine, zygadenine, veracerine, germine, protoverine, and their esters) (Gaillard et al., 2001). Protoverine A and B reduce oxygen in the blood, manifested by respiratory problems where with the animals are confronted (Chaney, 2015). Veratridine, protoverin, jervine, is neurological and cardiac toxins comparable to Digitalis who acts through an increase in the intracellular concentration of sodium instead calcium (Gaillard et al., 2001). It causes specific manifestations, namely: blurred vision, transitional blindness; dizziness;cardiovascular, respiratory disorders: slow and irregular pulse, slow and deep breathing, hallucinations; lack of muscle coordination, locomotor ataxia, seizures; gastrointestinal disorders: nausea, vomiting (Gaillard et al., 2001), abdominal pain (Gilotta et al., 2010), diarrhea, skin irritation (Wink., 2009).

According to Manceanu quoted by Zanoschi et al. (1981) the total amount of alkaloids in the plant is $0.6-0.7 \%$, which is not lost by drying the plant. The dose of fresh lethal roots for cows is $2 \mathrm{~g} /$ $\mathrm{kg}$ body weight. The cessation of bulbar nervous activities that control circulation and breathing lead to the death of animals. On the other hand, the consumption of this plant affects the pregnant cows which will give birth to some calves with defects (Chaney, 2015); jervine, cyclopamine causing malformations (cyclopean eye) which means, the presence of one eye at the center of the forehead to the fetuses (www.thepoisongarden. co.uk).

The toxic potential is greatly reduced by frost (Kerr, http://extension.wsu.edu/).

Bittersweet, bittersweet nightshade, popular names of the plant Solanum dulcamara, is a plant with a wide spread: from the plain to the subalpine level (www.geomorphologyonline.com,).

All parts of the plant are toxic, the tender peaks, seeds, but especially berries (Glen, 2008).

The intoxication is given by the solanidine and steroidal alkaloids solanine (https://csuvth. colostate.edu/), which interferes with digestion by inhibiting the vegetative nervous system and parasimpatic and direct irritation of the digestive tract (Schivera et al., 2011).

It can cause serious poisoning through consumption, regardless of whether the plant is green or found in hay. The forms of intoxication have wide spread: from mild to chronic, where, after Bosworth (2006), small, but, daily amounts of the plant ingested by the animals induce chronic intoxication manifested by: general unthriftiness, depression, diarrhea or constipation. Neurodigestive symptoms occur in the subacute form of intoxication and, in severe, acute forms, signs are nervous caused by the damage to the nervous system by solanine (Glen, 2008).

On the whole, the clinical signs of cows poisoned with Solanum dulcamara translate through: loss of appetite, salivation, pupil dilation, abdominal pain, gastric lesions, inflammation of intestinal mucous membranes, diarrhea that may become bleeding (Forero et al. 2011).

Sometimes the symptoms are more extensive, affecting the kidneys with manifestation of nephritis. Hemoglobinuria may occur as a result of the action of solanin in the blood, causing hemolysis of erythrocytes and urine staining in red (Zanoschi et al., 1981). In severe cases of intoxication cows manifest: vomiting, pupil dilatation, difficulty in breathing, diarrhea, paralysis, and death of animals (Chaney, 2015).

Chelidonium majus (Greater celandine) is a common plant throughout the country. It contains a bitter alkaloid stored especially in the root (chelidonine) which does not seem to be toxic, but at least another 20 alkaloids are found in the various organs of the plant dependent on the growth stage (Frohne et al., 1983) of which 
chelerythrine it is poisonous for cows (http:// poisonousplants.ansci.cornell.edu/, 2015). Other principles present: protopine, sanguinarine, berberine, tetrahydrocoptisine (https://research. vet.upenn.edu,).

The plant does not have a high degree of palatability, therefore, because of the sour and spicy taste, but, also the fetish smell, repulsively, is avoided by cows (Pădeanu, 2017). The toxic part of the plant is the light yellow liquid, which in contact with the air becomes reddish (http:// www.cbif.gc.ca,). Consequently, consumption of the whole plant has a toxic effect by ingestion (www.lancastercountyplanning.org/, 2010), the effects being: narcotic, emetic, purgative and manifestations of intoxication: drowsiness, salivation, staggering gait, staggering, convulsions, death.Calves consuming cow's milk with symptoms of intoxication are not affected, but necropsy reveals gastrointestinal irritation (http://www. cbif.gc.ca, 2014). The plant has irritating effect on the eyes and the skin if, the animals come into contact with it (Thomson, 2007).

\section{POISONING WITH PLANTS CONTAINING GLYCOSIDES}

As a rule, animals do not consume these plants, most of them having flowers.However, if there is no selective consumption due to poor productive capacity of pastures, they will be consumed by animals (Popescu et al., 1981). Among the plants that contain glycosides, Digitalis purpurea (Foxglove), protected species is very common among spontaneous flora species present in the meadows, forest edges or in glades, steppe grasslands (dry) which of ecological quality is medium-high, frequently burned in the spring, of the plain and hill areas (Akeroyd et al., 2012).

Contains as principles, cardiotoxic glycosides: digitalin, digoxin and digitoxin, both, in green and dry plants (Kerr, http://extension.wsu.edu). In addition, it possesses a saponin-digitonin and digilanides $\mathrm{A}, \mathrm{B}$ and $\mathrm{C}$, accumulated in leaves, stem, seeds, flowers (Kormanik, 2016). So, all parts of the plant are toxic (http://www. smallholderseries.co.uk,). The highest proportion of these toxic principles is found in the leaves and the action is cumulative. The lethal dose is 160$200 \mathrm{~g}$ for ruminants, signs of intoxication being of cardiovascular and gastrointestinal nature (http:// www.smallholderseries.co.uk/,) manifested by: abundant salivation, nausea, vomiting, colic, diarrhea (http://www1.agric.gov.ab.ca, 1995, 2010), polyuria, albuminuria, haematuria.

The cardiotoxic activity of glycosides is due to inhibition of ATPase transport and increased myocardial contractility (Dąbrowski et al., 2005). Signs characteristic of cardiovascular poisoning: the alternation between bradycardia - tachycardia and periods of arrhythmia; high blood pressure. In serious cases of intoxication, the chance of survival animals is null, death occurring by asphyxiation. To avoid intoxication, the hay should not contain more than $0.5 \%$ Digitalis.

Digitalis lanatum, in our country grows spontaneously in meadows, stony places and glades (www.wikipedia.ro/). It contains as main cardiotonic glycosides: diginatoside, lanatoside D, lanatoside A, lanatoside C, lanatoside E, lanatoside B, digoxigeninmonodigitoxoside, digoxigeninbisdigitoxoside, digoxin, glucocytofucoside, strospezid. Of the saponins, plant contains: digitonine, gitonine, tigonine (Zanoschi etal., 1981), and other principles as well: antirhinic acid, digitalosmin, and digitoflavoneus (http://poisonousplants.ansci.cornell.edu, 2015). Leaves, roots and seeds are the most toxic parts of the plant causing heart disease. Poisoning is manifested by: nausea, vomiting, diarrhea, slowed/ abnormal heartbeat, hallucinations (Tikofsky, 2013).

Another plant that contains the same cardio toxic principles is Adonis vernalis, widespread in the pastures, grasslands, glades, scarp; having like spreading area: the plain area up to the region of the high hills, but, more widespread in the limestone areas of the plateau and hill areas of the Romanian Subcarpathians, in the counties: Cluj, Bistrița-Năsăud, Alba, Hunedoara, Sibiu, Mureș, Dobrogea (https://dianthus2rt.wordpress.com, 2011).

Contain cardenolides toxic especially in leaves and flowers (Forero et al., 2010). The whole plant contains adonitoxin which causes cardio-vascular disorders by inhibit $\mathrm{Na}+\mathrm{K}+-$ ATPase (Wink, 2009), externalized by: weak pulse then accelerated, pronounced and progressive heart failure. Cardenolides causes gastrointestinal disorders such as: colic, haemorrhagic enteritis, diarrhea, decreased intestinal motility; nephritis and morphopathological changes: dilated cord (atrial dilatation), pulmonary with venous stasis (www. 
scritub.com,). Sometimes the end is undesirable: the death of the animals (Puschner et al., 2003). Symptoms would not be completely without longlasting diarrhea, stubborn to treatment, polyuria (Zanoschi et al., 1981). According to the same author, none of the glycosides disappear by boiling, and in the hay, the weight of this plant should not exceed $1 \%$.

The whole plant of Convallaria majalis is toxic because it has over 20 cardiac glycosides and saponins (Wink, 2009). The poisoning is severe by affecting the cardiovascular system. The plant contains convallarin (http://poisonousplants. ansci.cornell.edu, 2015); cardiac glycosides (https://www.coursehero.com, 2015), which causes painful burns in the mouth and throat, salivation, nausea, vomiting, abdominal pain, pupils dilation, slow and irregular heartbeats, hypertension, sometimes coma and death (Wink, 2009; Chaney, 2015).

Helleborus purpurascens, has as a spreading area: the beech and spruce forests, from the altitude of 300 meters inside the Carpathian arch and from 500 to 600 meters in the rest. Because it is a calcite plant, it does not grow on acidic lands, but it appears around limestone rocks (https:// ro.wikipedia.org,). Contains 3 active principles: heleborine, alkaloid - drastically purgative; heleborein, saponin acting on the nervous system causing narcosis and anesthesia and a steroidal glycoside with cardiotonic action, hebrin, to which is added ecdysteroids and $\gamma$-lactones (protoanemonin) (Maior et al., 2013). Because of these principles, the signs of intoxication manifested by cows are: digestive, nervous, cardiac. Cows exhibit inappetence, vomiting, gastroenteritis (Paul, 2007). At the cardiac level manifestations include: slow heart rate, with periods of arrhythmia, difficulty breathing. Muscle tremors are usually preceded by coma and death by asphyxia. It is not recommended to consume milk from poisoned cows because it causes diarrhea and vomiting (Zanoschi et al., 1981).

Poisoning with plants containing cyanogenic glycosides

Plants of the genus Sorghum. S. halepense (Johnson grass), a naturalized and invasive plant present in Romania's spontaneous flora (Sîrbu, 2012), under certain soil and climate conditions, ie frost or drought, contain a cyanogen nitrile glycoside (durrhin) whose toxicity level is low, after Knight (2007). Durrhin, by hydrolysis at an alkaline $\mathrm{pH}$ or by crushing the plant, decomposes into glucose, oxybenzoic acid and hydrogen cyanide which inactivate cell ferments and produce respiratory center paralysis (Popescu et al., 1981) and cardiac arrest (D’Mello, 2002).

Poisoning is manifested by hind limb paralysis, paresis, death through anoxia (Man, 1986). The parts of the plant with a high concentration of cynide are: strain and leaves, but, the young shoots are the most toxic (Fishel F., 2001).

The animals will not be allowed to grazing the sorghum before the dew rises because it exacerbates the toxicity of the plant. Other cases in which toxicity is manifested are: the consumption of green sorghum during or after rain or bumpy days, or when animals are hungry and consum a great quantity of plant in to short time (http:// www.dpi.nsw.gov.au, 2007). Poisoning usually occurs after a period of drought followed by rainy weather when the amount of hydrogen cyanide reaches $1 \mathrm{mg} / \mathrm{kg}$ of live weight (El Mahdy, 2015).

Prevention measures consist of avoiding grazing or sorghum consumption in rainy weather. In hay or silo the toxicity of durrhine is lost (Luginbuhl, 2015). Whatever the variety, Sorghum contains between 400-900 ppm cyanide by dry weight, which is why it is difficult to set a limit due to many factors, but $600 \mathrm{ppm}$ is considered a dangerous threshold and sometimes $200 \mathrm{ppm}$ for starving animals. (https://www.daf.qld.gov.au/, 2013).

Sambucus nigra (Elderberry), common species from the plain to the lower floor of forests, meadows, shrubs, (Zanoschi et al., 1981), is particularly present on soils rich in nitrogen, phosphate and potassium (Atkinson et al., 2002), but, poisoning are rare (DiTomaso, http://wric. ucdavis.edu,).

Palatability is differentiated over seasons, less in the spring and with greater expansion in late summer and autumn (Stevens et al., 2003). All parts of the plant: bark, leaves, mature fruit, unripe berries, roots, stems (Cooper et al., 1984), by ingestion produce poisoning in mild or moderate forms (Gough, 2010).

Cyanogenic glycoside, sambunigrine is present in the leaves (Long, http//books.google.ro/), fresh fruits contain hydrogen cyanide (Zanoschi 
et al., 1981), and those unripe, samburigrine (EMA/HMPC/44208/2012). Another cyanogenic glycoside is vicianine (Tewe et al., 1989), to which, it is added purgative substances (www.weeds. mangrovemountain.net, 2008); sambucinealkaloid, plus triterpenoides, resins, lecitins (Knight, 2007). Cyanogenic glycosides, by enzymatic or acidic hydrolysis, release cyanogenic acid, which inhibits enzymes that play a role in tissue respiration, producing histotoxic hypoxia. In small quantities it causes purging, and large ingested quantities induce animal depression. It is a violent emetic, animals displaying cathartic effect with diarrhea, abundant diuresis, accelerated pulse (Long, http//books.google.ro,). The nausea is caused by raw fruits (Chaney, 2015).

\section{POISONING WITH PLANTS CONTAINING OTHER TOXIC PRINCIPLES}

Euphorbia spp.,(spurges) is part of the category of toxic plants for cows and not only (DiTomaso, http://wric.ucdavis.edu,), but it is rarely consumed due to low palatability (Bosworth, 2006). Spread: All the country! Grows in pastures, cultivated places, vacant lands (Zanoschi et al., 1981).

In contact with the sap that has a high content of euphorbon (Beardsley et al., 1983) it is noted severe irritation of the skin, with the emergence of blisters (Glen., 2008).

Manifestations in case of consumption occur 1-2 hours after ingestion and are translated by: salivation, vomiting, burning irritation in mouth, throat and eyes, abdominal pain, diarrhea often haemorrhagic, muscle trembling, sweating, due to euphorbia, which in addition causes nervous and, cardiac disorders (Zanoschi et al., 1981), manifested by: arrhythmia, tinnitus, kidney and liver disorders, coma and in addition is cocarcinogenic (Wink, 2009).

The dominant clinical sign in fatal cases is blood-borne diarrhea due to haemorrhagic enteritis. Also, it can be notice: the depreciation of organoleptic quality of milk, which has reddish color, bitter taste and more, is toxic, that is why it is avoided to be consuming (Robinson, 2011).

The hay should not contain more than $1 \%$ of Euphorbia spp. and Mercurialis annua of the composition of the plant mixture, because because, by drying they lose out of toxicity but, do not completely disappear (Gligor et al., 1971). As a spreading area Eupatorium spp., is found in the meadows of the plains and mountain areas, terraces, virgin land (Enache, 2012).

Eupatorium rugosum (white snakeroot), E. ageratoides, E. urticaefolium and the newest invasive plant Eupatorium cannabinum - boneset (http://issg.org/,) are plants of high toxicity especially at the end of the summer or when, by overproduction, the feed is insufficient (Bosworth, 2006).

From the parts of the plant, stems and the leaves are the most toxic, because of tremetol that causes the disease called "trembles", and the symptoms are manifested by: muscle tremors especially in the nose and legs, especially of the flank and hind legs (http://poisonousplants. ansci.cornell.edu, 2015), deficiency to stay in standing position (Beardsley et al., 1983), stiff gait, depression, periods of sweating, normal or subnormal body temperature, labored or shallow respiration, partial throat paralysis, jaundice, passage of hard feces, prostration, death. The effect of consumption is cumulative, poisoning may occur at the consumption of $1-20 \%$ of the body weight and occurrence of poisoning manifestations within 2 days to 3 weeks (http://poisonousplants.ansci. cornell.edu, 2015). Because the toxin is eliminated through milk, cows will show signs of poisoning later (Spaink, 2003).

The toxic effect of Eupatorium consumption does not only occur directly on animals but, the toxin absorbed in milk or meat, products derived from poisoned animals also affects consumers to which it provokes "milk disease", butter or meat (Robinson, 2011, https://zidbits.com/, 2011/).

Pteridium aquilinum (Bracken fern). All parts of the plant are toxic (Knight, 2007), having several principles: ptaquiloside - unstable glycoside (German, 2017) that, under alkaline conditions is transformed into conjugated dieneone which is readily added to various nucleophilic compounds, the exerted action being positively carcinogenic (http://ethnobotanical.info,); at least two carcinogenic potential principles: quercetin şi kaempferol (http://ethnobotanical.info,); prunasin which are glycoside; thiaminase, an enzyme that reduces the thiamine reserve of the body, present in the leaves and root (Stegelmeier, http://www.msdvetmanual.com; http://www. pfaf.org,). In cattle, the effect is cumulative, the plant having direct or indirect anticoagulant properties, 
signs of intoxication occurring after 1-2 months from feed consumption containing more than $30 \%$ bracken fern (https://documents.tips,). Animals are listless, weight loss, bleeding on the mucous and internal membranes, anemia (Schivera et al., 2011), high fever, (Bosworth, 2006), abundant salivation, petechial hemorrhages, haematochezia, bright blindness (http://vetbook.org,). Nasal and rectal haemorrhages, difficulty in breathing, blood in urine and faeces, haemorrhagic syndrome, induces immunotoxic effects (Latorre et al.,2011), aplastic bone marrow, (https://www.ars.usda. gov,) leading to severe leucopenia, tombocytopenia (Bradley, www.chm.bris.ac.uk,), bladder and intestinal carcinomas, urinary bladder neoplasm of various tissue types and epithelial tumors of the upper gastrointestinal tracts of ruminants (Panter et al., 2011). Symptoms are dependent on the severity of poisoning.

Thus, in mild cases, acute dermatitis is noted on the nasal bridge which are a tell-tale, and in severe cases two different syndromes are distinguished: first, acute hemorrhagic syndrome translated by bone marrow depression and urinary tumors that is considered the second syndrome (http:// vetbook.org,).

Young animals can develop swelling in the larynx and may have respiratory problems due to laryngeal and perilaryngeal edema (Mc Kinnon, http://www.ava.com.au,) called hematidosis, blood sweat, or Keridilis's disease (https:// documents.tips,).

The second form of intoxication mentioned by the same authors is enteric, which precedes laryngeal form and which is manifested by bloody feces, hematuria, the blood coagulates hard, since there is a deficiency of platelets. After German (2017), thiaminase does not obviously affect ruminants because ruminal bacteria degrade the enzyme, but, most likely ptaquiloside affect bone marrow. The same principle is incriminated in soil pollution and can reach in drinking water (http:// ethnobotanical.info,). Health damage is reversible if thiamine is administered in a timely manner. The immunodepresive effect of ptaquiloside can be prevented by selenium supplementation (Latorre et al., 2011). The possibility of consumer poisoning through the milk obtained from cows that have ingested this plant is possible (Chaney, 2015).

\section{THE REVERSE OF THE COIN: THE POSITIVE EFFECT OF TOXIC PLANTS}

Although intoxications are imminent in the case when the proportion of toxic plants is high in floral composition, should not be undermine the beneficial, healing effect of these, which may come to the aid of medicine, and considered "the gift of God to mankind" in Hindu mythology (Lans et al., 2007), that, can be harvested at the end of August, early September. Ethnoveterinary research is defined as "the systematic investigation and application of folk veterinary knowledge, theory and practice" (Schmid et al., 2012).

Veratrum album.Has been used since the Middle Ages in Europe as an emetic for cows (Lans et al., 2007). In folk medicine Veratrum is used as well against irritation in neurologia, tonic cardiac due to its content in alkaloids with antihypertensive action (Schmid et al., 2012).

Roots of de Veratrum album are used as tea in the treatment of diarrhea in calves (Bartha et al., 2015). Root dried and smeared onto the hair or boiled in combination with Brassica oleracea leaf sap are used in the fight against lice to large and small ruminants (Gub , 2005).

Applying the leaves in the form of a blanket or in the form of a powder obtained from the drying of the plant Chelidonium majus, is used in veterinary treatment to combat scabies in animals. The aerial parts of the plant mixed with forage are used to treat intestinal infections in cows and the decoction of Chelidonium majus can be given to cows for the elimination of placenta (Vlková et al., 2015). Among the plants with anti-parasitic effect, white lupine (Lupinus albus) is beneficial. In fact, it is the only plant that can be applied directly to the skin of the animals (Tikofsky., 2013), or by boiling lupine seeds which, due to their high alkaloid content, give a bitter taste. These, after boiling, are applied to the skin of animals having a repellent and aficid effect (Bischoff et al., 2016).

Nicotiana tabacum, is used in the treatment against ectoparasites (Bischoff et al., 2016). Nicotine sulphate extracted from Nicotiana tabacum, is used to eliminate gastrointestinal nematodes: Monezia, Ascaridia and other parasites (Laudo et al., 2013).

According to the same author Belladonna is used in: high fever systemically and locally and the tissue is bright red or red streaked and painful such as acute mastitis (McCrory, 2012).The parts 
used in the plant Eupatorium perfoliatum: Leaves, flowers, have an effect immune stimulant, reduce bone pain, fever (Tikofsky, 2013)

In the heart diseases the parts of the plant Digitalis lanata: leaves, roots, seed have homeopathic effect (Tikofsky, 2013). Convallatoxin and convaloside from Convallaria major can be used as an alternative to Digitalis cardiac failure treatment (Laudo et al., 2013). Convallatoxin, from the blossoms, is used as a cardiotonic. The dried rhizome, known as Convallaria root, has also been used as a cardiotonic and diuretic. In veterinary science it has been used as a diuretic and cardiac stimulant (http://poisonousplants.ansci.cornell. edu, 2015).

In Romania, but also countries such as Italy, Turkey, Serbia, the roots and branches of Hellborus spp. are inserted under the skin of sick animals to treat respiratory problems (Maior et al., 2013). At cattle, Helleborus purpurascens roots are inserted in the outer ear to treat inflammation (Vlková M., et al., 2015), the petiol of Helleborus bocconei are insered into the ear or the neck for bronchitis the leaves of Helleborus foetidus are inserted into the ears for bronchitis and pneumonia ( Bartha et al., 2015),

Equisetum arvense is used to maintain the mineral balance during the period of calving (http://www.bionaturesanteanimale.fr,).

For prevention and therapy of false gestation it is indicated Senecio vulgaris, which promotes estrogen secretion and inhibits the secretion of progesterone (Laudo et al., 2013)

Sambucus nigra - elderberry may be effective for the treatment of gastrointestinal disorders, such as colic, impaired digestion, tympany, and meteorism (Mayer et al., 2014). Sambucus nigra flower as a decoction has diuretic effect; the flower in fumigation used for inflamed udder, mastitis (Bartha et al., 2015). "Elderberry flowers contain flavenoids and rutin, which are known to improve immune function, particularly in combination with vitamin "C." The flowers also contain tannins, which account for its traditional use to reduce bleeding, diarrhea, and congestion" (Stevens, 2003).

\section{CONCLUSION}

Not all animal species react in the same way to the action of a substance present in plants, but the strategy of good management of pasture and grazing is the main desideratum for maintaining the integrity of health and productive performance in cows.

Although plants with toxic potential may also have beneficial effects being used in Ethnoveterinary.

\section{REFERENCES}

1. Aboling S, Rottmann S, Wolf P, Jahn-Falk D, Kamphues J (2014). Case Report: Complex Plant Poisoning in Heavily Pregnant Heifers in Germany. J. Vet. Sci. Technol. 5: 178

2. Acamovic T, Stewart CS, TW Pennycott (2004). Poisonous Plants and Related Toxins, chapter 4, pg 38, CABI publishing

3. Akeroyd J, Bădărău S (2012). Specii de plante indicatoare pentru pajiști cu Înaltă Valoare Naturală din sudul Transilvaniei). Ed: Fundația ADEPT Transilvania

4. Anadón A, Martínez-Larrañaga MR; Castellano V (2012). Poisonous plants of Europe. In Veterinary Toxicology: Basic and Clinical Principles, 2nd ed.; Gupta, R.C., Ed.; Elsevier Inc.: San Diego, CA, USA.pp. 1080-1094.

5. Arnold GW, Morley FHW (1981). Grazing behaviour. Grazing animals. Elsevier. p. 79-104

6. Atkinson MD, Atkinson E (2002). Sambucus nigra L., Journal of Ecology 90: 895-923

7. Bhat R, Ravishankar VR, Karim AA (2010). Mycotoxins in Food and Feed: Present Status and Future Concerns, Comprehensive Reviews in Food Science and Food Safety, Vol.9 ( 1): 57-81

8. Baldwin L, Boswell M, Burgess D (2011). Livestock poisoning plants of whatcom county pastures, www. whatcomcounty.us/publicworks/weeds/index.jsp

9. Bartha SG, Cassandra L Quave CL, Lajos Balogh L, Nóra Papp N (2015). Ethnoveterinary practices of Covasna County,Transylvania, Romania. J. of Ethnobiology and Ethnomedicine (2015) 11:35, DOI 10.1186/s13002-0150020-8

10. Beardsley L, Sloot J (1983). Poisonous plants of the Midwest, http://www.archive.org/details/ poisonousplants

11. Benedict GT, Lee S T, Panter KE, Brown DR (2012). Review. Piperidine alkaloids: Human and food animal teratogens. Food and chemical toxicology, vol 50: 2049-2055

12. Binev R (2010). Intoxication by JimsonWeed (Datura stramonium) in animals. Ecol. Future Bulg. J. Ecol. Sci. 9: 9-16.

13. Binev R, Mitev J, Miteva T (2007). Intoxication with Poison Hemlock (Conium maculatum L.) in calves. Trakia J Sci 5: p 40-50

14. Bischoff T, Vogl C R., Ivemeyer S, Klarer F, Meier B, Hamburger M (2016). Plant and natural product based homemade remedies manufactured and used by farmers of six central Swiss cantons to treat livestock. Livestock science vol.189,p.110-125

15. Bischoff T, Vogl CR, Ivemeyer S, Klarer F, Meier B, Hamburger M (2016).Plant and natural product based homemade remedies manufactured and used by farmers 
of six central Swiss cantons to treat livestock. Livestock science vol.189, p.110-125

16. Boyd J, Yelverton F, Murphy T, Plants poisonous to livestock in the Southern US, https://www.uaex.edu/

17. Bosworth S (2006). Plant Poisoning of Livestock in Vermont www.uvm.edu/

18. Bradley D, Ptaquiloside - The poison in bracken, http:// www.chm.bris.ac.uk/

19. Chaney M (2015). Livestock - Toxic Plants http://www. piercecountycd.org/

20. Chan TY (2009). Aconite poisoning. Clin Toxicol (Phila),vol. 47(4),p.279-285

21. Constable PD, Hinchcliff KW, Done SH, Gruenberg W (2017). Veterinary Medicine - E-BOOK: A textbook of the diseases of cattle, horses sheep, pigs and goats , Chapter 21. Sistemic and multi-organic disease, pg. $2196 \mathrm{Ed}$ Elsevier

22. Cooper M R, Johnson AW (1984). Poisonous plants in Britain and their effects on animals and man. Her Majesty's Stationery Office, London, England. 305 pp.

23. Cortinovis C, Caloni F (2015). Alkaloid-Containing Plants Poisonous to Cattle and Horses in Europe, Toxins 7(12) p. 5301-5307

24. Dąbrowski WM, Sikorski ZE (2005). Toxins in Food, CRC PRESS, Boca Raton London New York Washington, D.C.

25. Daunoras G (2012). Veterinary Toxicology. Lecture notes and classes works www.esparama.lt/

26. David NW (1997). Poisonous Plants and Animals of Florida and the Caribbean, Pineapple Press Inc, Florida pg.74

27. DiTomaso JM. List of plants reported to be poisonous to animals in the United States http://wric.ucdavis.edu/

28. D’Mello JPF ( 2002). Contaminants and toxins in animal feeds, http://www.fao.org/

29. Drăghici C (1991) Animal hygiene and environmental. Ed Academicpres, Cluj- Napoca

30. El Mahdy C (2015). Zoo hygiene. Vol II "Artificial Environmental Factors and Their Influence on Animal Welfare, Health and Animal Production"Ed Napoca Star,Cluj Napoca

31. Everest J W, Powe Jr TA., Freeman JD (2005). Poisonous Plants of the Southeastern United States, www.aces.edu./

32. Fishel F (2001) - Plants Poisonous to Livestock, https:// extensiondata.missouri.edu/

33. Forero L, Nader G, Graaigmill A, diTomaso J M, Puschner B, Maas J (2010).Livestock-Poisont plant in California http://anrcatalog.ucdavis.edu

34. Frohne D, Pfander H J (1983). A colour atlas of poisonous plants. Wolfe Publishing Ltd., London, England. 291 pp.

35. Fuchs J, Rauber-Lüthy C, Kupferschmidt H, Kupper J, Kullak-Ublick GA, Ceschi A (2011). Acute plant poisoning: analysis of clinical features and circumstances of exposure. Clin Toxicol 49: 671-680

36. Gaillard Y, Gilbert P (2001). LC-EI-MS determination of veratridine and cevadine in two fatal cases of Veratrum album poisoning. J.of Analytical Toxicology, vol. 25: 481485
37. Galey FD, Holstege DM, Fisher EG (1992). Toxicosis in dairy cattle exposed to poison hemlock (Conium maculatum) in hay: isolation of Conium alkaloids in plants, hay, and urine. J. Vet Diagn Invest 4:60-64

38. Garland Tam, A. Catherine Barr (1998). Toxic Plants and Other Natural Toxicants, CABI publishing, pg 224

39. German J (2017). Brackenfern (Pteridium aquilinum) http://www.goatworld.com/

40. Gilotta I, Brvar M (2010). Accidental poisoning with Veratrum album mistaken for wild garlic (Allium ursinum). Clin Toxicol (Phila) 48:949-952. doi:10.3109/15563650.2010.5

41. Glen N (2008). Guide to Toxic Plants in Forages WS-37 www.extension.purdue.edu/new

42. Gough RE (2010). Poisonous plants in the home landscape www.msuextension.org

43. Gub J (2005). Népi növényismeret a Nagy-Homoród mentén. In: Zsigmond G,editor. Növények a folklórban. Bucharest: A Magyar Köztársaság Kulturális Intézete p. 148-62

44. Hansen P, Clerc B (2002). Anisocoria in the dog provoked by a toxic contact with an ornamental plant: Datura stramonium. Vet Ophthalmol 5:277-279

45. Hart CR, Garland T, Barr C, Carpenter BB, Reagor JC (2001). Integrated Toxic Plant Management oaktrust. library.tamu.edu

46. Hassine TB, Mansour AB, S. Hammami (2013). Case report of fatal poisoning by Nicotina tabacum in cattle in Tunisia. Revue Méd. Vét., 164 ( 3):141-144

47. Johnson RC, Lemire SW, Woolfitt, AR, Ospina M, Preston KP, Olson CT, Barr JR (2005). Quantification of ricinine in rat and human urine: a biomarker for ricin exposure. J.of Analytical Toxicology. 29(3): 149-155

48. Jonker J (2015). Datura spp.(Jimsonweed, Downy Thornapple, Devil's Trumpet, and Angel's Trumpet) http://poisonousplants.ansci.cornell.edu/

49. Kerr SR. Selected Poisonous Plants of the Pacific Northwest, http://extension.wsu.edu/

50. Knight AP (2007). Guide to Poisonous Plants. http:// southcampus.colostate.edu/

51. Kormanik M (2016). Pretty, Deadly: 8 Toxic Plants Commonly Grown in Midwest Gardens. www.greenwise. $\mathrm{com} /$

52. Lans C, Turner N, Khan T, Brauer G, Boepple W (2007). Ethnoveterinary medicines used for ruminants in British Columbia, Canada, J Ethnobiol Ethnomed; 3: 11. , doi: 10.1186/1746-4269-3-11

53. Largo M (2014). Big, Bad Botany: Deadly Nightshade (Atropa Belladonna), the Poisonous A-Lister. The Big, Bad Book of Botany: The World's Most Fascinating Flora

54. Latorre AO, Caniceiro BD, Wysocki Jr HL, Haraguchi M, Gardner DR, Górniak SL (2011). Selenium reverses Pteridium aquilinum-induced immunotoxic effects. Food and Chemical Toxicology vol 49, (2): 464-470

55. Laudato M, Capasso R (2013). Useful plants for animal therapy.A alternative medicine. www.oapublishinglondon. com/ 
56. Luginbuhl JM (2015) Poisonous Plants to Livestock https://content.ces.ncsu.edu/

57. Lyons RK, Machen RV (2000).Interpreting Grazing Behavior. Texas AgriLife Extension Service. Grazing ManagementHohlt, J.C

58. Maior MC, Cristia Dobrotă C (2013). Natural compounds with important medical potential found in Helleborus sp. Cent. Eur. J. Biol. 8(3) : 272-285

59. Maior MC, Dobrot C (2013): Natural compounds with important medical potential found in Helleborus sp. Cent Eur J Biol 2013; 8: 272-285.

60. Man C (1986). Zoo hygiene. Course Tipo Agronomia, Cluj - Napoca

61. Markéta T, Petra Vyzínová P (2006). Field Crops, https:// cit.vfu.cz/

62. Mayer M (2014). Complementary and alternative medicine on italian organic farms and ethnoveterinary as a possible strategy for disease treatment

63. Mayer Maria (2014)-Complementary and alternative medicine on italian organic farms and ethnoveterinary as a possible strategy for disease treatment

64. Mc Kinnon R. Poisonous plants -A brief introduction http://www.ava.com.au/

65. McCrory L (2012). Homeopathy For Livestock http:// www.nofamass.org/

66. Meriçli AH. Pyrrolizidine Alkaloids, http://docs.neu.edu. tr/

67. Mezzasalma V, Ganopoulos I, Galimberti A, Cornara L, Ferri E, Labra M (2016). Poisonous or non-poisonous plants? DNA-based tools and applications for accurate identification. Int J Legal Med, DOI 10.1007/s00414-0161460-y

68. Nelson PD, Mercer HD, Essig HW, Minyard JP (1982). Jimson weed seed toxicity in cattle. Vet Hum Toxicol. 24(5):321-5

69. Nualláin FÓ (2014). Beware this Halloween: Poisonous plants that may be growing near you, http://www. irishexaminer.com/

70. Pădeanu I (2017). Păşunat fără intoxicaţii http://www. revista-ferma.ro/

71. Panter K E, James LF, Gardner DR (1999). Lupine, poisonhemlock, and Nicotiana spp.: Toxicity and teratogenicity in livestock. J. Nat. Toxins 8: 117-134

72. Panter KE, Ralphs M H, Pfister JA, Gardner DR, Stegelmeier BL, Lee ST, KD.Welch, Green BT, Davis TZ, Cook D (2011). Plants Poisonous to Livestock in the Western States, Bulletin Number 415 p. 1-120

73. Panter KE, Keeler R F, Lynn FJ, Bunch TD (1992). Impact of plant toxins on fetal and neonatal development: A review. J. Of Range Management 45(l): 52-57

74. Paul E (2007). Poisonous plants list Alpaca poison plants http://flowerdalealpacas.net/

75. Popescu D (1981). Livestock hygiene Ed. Ceres, București

76. Puschner B, Woods L (2003). Poisonous plants and effects on animals.In: Proceedings, California Alfalfa and Forage Symposium, 17- Cooperative Extension, University of California, Davis 95616 http://alfalfa.ucdavis.edu
77. Rasnoveanu M (2013). Cele mai otravitoare 10 plante din lume, http://www.ziare.com/

78. Schep L J, Slaughter RJ, Michael D, Beasley G (2009). Nicotinic plant poisoning. J. Clinical Toxicology vol. 47, issue 8: 771-781

79. Schivera D, Jean English J (2011). Poisonous Plants in Pastures. http://www.mofga.org/

80. Schmid K, Ivemeye S, Vogl C, Klarer F, Meier B, Hamburger M, Walkenhorst M (2012). Traditional Use of Herbal Remedies in Livestock by Farmers in 3 Swiss Cantons (Aargau, Zurich, Schaffhausen) Forsch Komplementmed;19:125-136 ,DOI: 10.1159/000339336

81. Seceleanu C (2015). Fauna României, http://www. faunaromaniei.ro/

82. Soler-Rodríguez F; Martín A.; García-Cambero JP, Oropesa AL, Pérez-López M (2006). Datura stramonium poisoning in horses: A risk factor for colic. Vet. Rec,vol. 158:132-133

83. Sârbu C (2012). Plante de carantină invazive în România, http://www.uaiasi.ro/

84. Spaink K (2003). Natural poisons, www.spaink.net/

85. Stegelmeier B L. http://www.msdvetmanual.com/ toxicology/

86. Stevens M (2003). Plant guide-common elderberry Sambucus nigra L. ssp. canadensis (L.) R. Bolli http:// plants.usda.gov/

87. Stevens M, Nesom G (2003). Plant guide common elderberry Sambucus nigra L. ssp. canadensis (L.) R. Bolli http://npdc.usda.gov/

88. Tewe 00, Iyayi E A (1989). Cyanogenic glycosides. Pages 43-60 in Cheeke, P. R., ed. Toxicants of plant origin. Vol. II. Glycosides. CRC Press, Inc., Boca Raton, Fla., USA. 277 pp.

89. Thomson N (2007). Poisonous Plants in Australia: Enabling consumers to buy safe plants, WWF-Australia Issues Paper. WWF-Australia, Sydney,

90. Tikofsky L (2013) .Organic Dairy Herd Health: Alternative and Complementary Treatment and Medicines http:// articles.extension.org/

91. Tikofsky L (2013). Organic Dairy Herd Health: Alternative and Complementary Treatment and Medicines http:// articles.extension.org/

92. Vlková M, E. Kubátová, P. Šlechta Z. Polesný, (2015). Traditional use of plants by the disappearing Czech diaspora in Romanian Banat, Scientia agriculturae bohemica, 46, (2): 49-56

93. Voia S, Drinceanu D (2009). Plante toxice în hrana oilor şi a caprelor

94. Walsh R B, Dingwell RT (2007) Beef herd poisoning due to ingestion of tansy ragwort in southwestern Ontario, Canada. Vet J. 48(7): 737-740.

95. Welch KD, Panter KE, Gardner DR, Stegelmeie BL (2012). The Good and the Bad of Poisonous Plants: an Introduction to the USDA-ARS Poisonous Plant Research Laboratory, J. Med Toxicol.; 8(2): 153-159, doi: 10.1007/s13181-0120215-5

96. Wilson CR, Sauer J, Hooser SB (2001). Taxines: A review of the mechanism and toxicity of yew (Taxus spp.) alkaloids. Toxicon, 39:175-185. 
97. Wink M. (2009). Mode of action and toxicology of plant toxins and poisonous plants, Mitt. Julius Kühn-Inst: 93112

98. Wright B., Jansen J, Leuty T (2007). Yew Poisoning in Horses and Ruminants, http://www.omafra.gov.on.ca/

99. Zanoschi V, Turenschi E, Toma M (1981). Plante toxice în România. Ed Ceres, București

100. www.lancastercountyplanning.org/, 2010

101. EMA/HMPC/44208/2012-Assessment report on Sambucus nigra L., fructus)

102. http://www.plantpedia.ro/tisa-taxus-baccata/, 2010

103. http://agriculturaonline.blogspot.ro, 2011

104. http://ethnobotanical.info/pmwiki.php?n=Pteridium. Aquilinum

105. http://poisonousplants.ansci.cornell.edu/, 2015

106. http://poisonousplants.ansci.cornell.edu/toxicagents/ pyridine.html

107. http://poisonousplants.ansci.cornell.edu/yew.html

108. h t t p : / / ve t b o ok. org / wiki / c ow / in d ex. php?title=Bracken_fern_poisoning

109. http://www.belladonnakillz.com

110. http://www.biaplant.ro/, 2015

111. http://www.cbif.gc.ca, 2014

112. http://www.geomorphologyonline.com

113. http://www.pfaf.org

114. http://www.provet.co.uk/lorgue/5a77ff5.htm

115. http://www.realgardeners.co.uk/poisonousplants. htm\#S

116. http://www.sfatulmedicului.ro/
117. http://www.smallholderseries.co.uk/

118. http://www.thepoisongarden.co.uk/

119. http://www.triplecrownhorsefeeds.com/

120. http://www.weeds.mangrovemountain.net , 2008

121. http://www1.agric.gov.ab.ca, 1995,2010

122. https://dianthus2rt.wordpress.com,2011

123. https://documents.tips/

124. https://novascotia.ca/

125. https://research.vet.upenn.edu/

126. https://ro.wikipedia.org

127. https://web.archive.org/

128. https://www.ars.usda.gov/, 2016

129. https://www.business.qld.gov.au,2016

130. https://www.coursehero.com,2015

131. https://www.scribd.com/

132. www.co.lancaster.pa.us/ 2010

133. http://www.dpi.nsw.gov.au/,2007

134. www.envbop.govt.nz, 2003

135. www.rndr.ro/documente/, 2015

136. https://www.southernwoods.co.nz/

137. http://www.bionaturesanteanimale.fr

138. https://csuvth.colostate.edu/, 2017

139. http://www.welchproperty.com/

140. https://zidbits.com/,2011

141. http://issg.org/database/species/

142. https://www.daf.qld.gov.au/,2013

143. https://csuvth.colostate.edu/ 